tion to a given problem and their interpretation receives little or no attention. There is now available, however, a handbook ("The Application of Influence Lines to the Stress Analysis of Beams and Lattice Girders." By R. McCrae. Part 1. Pp. 42. (London : The Draughtsman Publishing Co., Ltd.) 2s.) which discusses fully their practical uses as they might be of advantage to a designer. The first part, which is now issued, deals with beams only. The author's primary object in Part 1 has been to provide the reader with a knowledge of the fundamental principles underlying the conception of influence lines. $\mathrm{He}$ shows how simple it is to construct the diagram for all cases and how the maximum effects due to rolling and distributed loads can be deduced. In the matter of units, it would have been an advantage to have described the ordinate of the bending moment influence line as representing ton-foot units per ton, so that when multiplied by the appropriate load the result is rational. Those who have been in the habit of using the bending moment diagram will at first find the influence line somewhat unorthodox but, once masters of the system, will doubtless agree as to its advantages, particularly in saving time and eliminating errors, and will appreciate the detailed treatment given in this publication.

\section{A Clarity Tester for Gelatine}

THE introduction of the various forms of rectifier photo-electric cell has certainly simplified many problems in the use of instruments such as colorimeters (chemical type), densitometers and the like, since currents of the order of 100 microamperes can be attained without very intense light, the cell acting, when suitably illuminated, as a primary source of direct current without the use of batteries. Many such applications have now been developed. A convenient instrument of this type has been recently designed by Messrs. Imperial Chemical Industries, Ltd., and put on the market by Messrs. Baird and Tatlock (London), Ltd., for the testing of the clarity of gelatine and other aqueous solutions. It is well made and easy to operate, and should be found of great assistance in saving time in such tests as well as in giving much better accuracy than visual comparisons. No doubt more or less empirical scales would have to be established for particular types of product, and in instruments of this kind (as indeed in visual photometry) it will be important to avoid confusion between scattering and direct absorption of light.

\section{Butane Gas Supply in Rural Areas}

IN an article in Engineering of May 8, Mr. Theodore Rich gives an account of the development of the use of bottled butane gas in rural areas with no gas or electricity supply in France, the United States and Great Britain. Butane $\left(\mathrm{C}_{4} \mathrm{H}_{10}\right)$ can be obtained from natural gas, crude oil or coal; it liquefies under a pressure of $23 \mathrm{lb}$. per sq. in. at $60^{\circ} \mathrm{F}$. At a temperature of $104^{\circ} \mathrm{F}$. the pressure of liquefaction is only $62 \mathrm{lb}$. per sq. in., and it can therefore be delivered to customers in comparatively light steel bottles. In France the bottles contain $28 \cdot 6 \mathrm{lb}$. of liquefied gas, which has a heat content of 21.590 B.Th.U. per lb. The cost works out at about $3 s$. a therm. It is distributed by several thousand agents, and the gas is used particularly for cooking, one bottle containing sufficient gas to cook for a family of three persons for six or seven weeks. At the Paris Fair of May 1935, practically every maker of gas stoves showed apparatus for the use of butane. The manufacture of butane and isobutane in Great Britain has been undertaken by Imperial Chemical Industries, Ltd., at Birmingham, and the gas is being marketed as 'Calor' gas. Butane can be used for gas fires, geysers and for house lighting, and in the villages of Smalldole in Sussex, Stokesley near Middlesbrough and Hay in Brecknockshire, it has been applied to street lighting.

\section{Solid $v$. Liquid Fuels}

IT is one of the characteristics of our times that science and technical effort make us largely inde. pendent of geographical circumstances. Products not occurring naturally may be synthesised, and under the plea of national self-sufficiency much may be done, even although entirely uneconomic when judged by former standards. Many things can be done with liquid fuel which are difficult or impossible with solid, and the natural result has been the development of the oil industry. The latest phase is the synthesis of liquids from coal by hydrogenation, and the technical merit of this achievement is apt to obscure the economic aspect. There are, however, still those who insist on the reversion to old standards, and a pamphlet issued by the Liberty Restoration League, 24 Essex Street, London, W.C.2, makes a plea for the return to coal and its products in place of oil for all purposes. It is claimed that the use of liquid fuels on land, sea and air is largely maintained by subsidy, open or concealed, which should be recognised and even curtailed. Much of the plea cannot be gainsaid, but neither the State nor the individual is likely to forgo powers conferred by liquid fuels. There is much to be said for greater efforts to transfer coal into products now in demand, but it is wholesome that the cost should be clearly understood.

\section{Institute of Wireless Technology}

THE annual general meeting of the Institute of Wireless Technology took place on April 30. Mr. James Nelson was elected president for the ensuing year and Mr. B. Tunbridge Hogben was re-elected hon. treasurer. The annual report showed a further increase of membership, and in particular it was noted that the student membership had increased to a greater extent in 1935 than in any previous year. The number of candidates for the associateship and associate membership examinations also showed an increase for the year under review. It should be mentioned that the subject of television has been included as a special subject for several years past, and this is believed to be the only examination for television engineers to be held by any professional institution in the country. The presidential address was entitled "The Value of the Institute to the Profession and Industry". 